\title{
Mellemrum tre - køn etnografi og antropologi
}

\author{
Af Tine TJørnhøj-Thomsen, \\ SEBASTIAN MOHR OG \\ Rasmus Prastmand Hansen
}

\section{MELLEMRUM}

Tine Tjørnhøj-Thomsen er professor (mso) på Statens Institut for Folkesundhed, Syddansk Universitet. Uddannet som antropolog på Københavns Universitet har hun særligt præget den del af den danske etnografiske kønsforskning, der beskæftiger sig med slægtskab, reproduktion og reproduktionsteknologier. Hendes ph.d.-afhandling Tilblivelseshistorier. Barnløshed, slagtskab og forplantningsteknologi i Danmark (Tjørnhøj-Thomsen 1999a) bygger på feltarbejde i Danmark blandt dem, der bruger fertilitetsbehandling som en vej ud af deres barnløshed. Temaredaktionen mødtes med Tine Tjørnhøj-Thomsen i december 2015 på hendes kontor på Statens Institut for Folkesundhed for at snakke om hendes akademiske arbejde og de udfordringer, som etnografisk kønsforskning byder på i krydsfeltet af køn, reproduktion og medicinsk teknologi.

\section{MERE END BARE FEMINISME - AKADEMISKE MILJØER OG KØN(SFORSKNING)}

En opmærksomhed på køn og kønsforhold skal udgøre en integreret del af den etnografiske opmærksomhed. Jeg kan i hvert fald ikke se det adskilt fra hinanden. Det kan godt være, at køn ikke nødvendigvis dukker op eller trænger sig på i den etnografiske analyse hele tiden, men jeg kan slet ikke forestille mig, at man skulle kunne adskille det fra det etnografiske arbejde. Jeg kan dog også godt huske, at selv om vi havde kvindegrupper på antropologi og læste Toward an Anthropology of Women (Reiter 1975) og også en dansk pendant, som bl.a. Susan Whyte havde bidraget til, så havde antropologi i en lang periode faktisk slet ikke en tradition for at tilbyde kurser i køn. Det var ikke en selvfølgelighed, at man blev introduceret til køn på antropologi. Og der var også en lang periode, hvor man havde en fornemmelse af, at det var lidt ugleset, hvis man bragte køn på banen. I den sammenhæng tror jeg, at sociologi har været 
meget mere up front og har haft et fokus på køn - på kvinder, køn og forskning så at sige - og vi er flere, der har haft mange dialoger med sociologi undervejs. Men det er som om, man holdt sig lidt tilbage på antropologi. Jeg kan huske, at jeg på et tidspunkt satte mig for at udbyde et kursus i Feministisk antropologi, og der kom stort set ingen studerende fra antropologi. Men til gengxld kom der studerende fra Lund, der kom studerende fra RUC, osv. Så kurset blev altså på en eller anden finurlig måde til noget, selv om der ikke var ret mange studerende fra instituttet. Og jeg kan også tydeligt huske dengang, da vi skulle præsentere vores kurser for vores kollegaer og for de studerende. Da jeg var færdig, var der en, der sagde om mit kursus: "Der var sgu lidt for meget lilla ble over det kursus". Det xrgrer mig, fordi jeg synes, at de ting, vi havde fat i på det kursus - vi diskuterede fx Haraway, Butler, Harding, altså dem, der virkelig havde noget at sige - de var dybt interessante og et eller andet sted mere end et kursus i feministisk antropologi. Det kursus var dybest set et udmærket indslag til grundlæggende videnskabsteorier. Jeg kan også huske en undersøgelse om kønsbarrierer på universitetet, og hvorfor kvinder ikke bliver akademikere, og hvordan de i øvrigt har det som akademisk ansatte på universitetet. Vi var en fire-fem kvinder, som kom fra ikke-akademiske hjem og kom til at tale om undersøgelsen. Vi blev meget hurtigt enige om på det tidspunkt, at det ikke var vores køn, der havde været en barriere, men vores ophav, altså det forhold, at vi ikke kom fra akademiske hjem og ikke besad den umiddelbare kulturelle kapital, som blev brugt på universitetet. Det var på mange måder en god idé, at man spurgte til kønnets betydning i denne sammenhæng, men når man sådan sad og tænkte over det, så kunne man godt se barrierer. Køn som barriere er dog utvivlsomt tilstede i mange af universitetets kontekster. Som lidt ældre forsker har jeg selv kæmpet meget mod men in black, som jeg kalder dem, altså de mænd, der på en eller anden gudsbenådet måde formår at ignorere kvinders tilstedeværelse og ytringer i forskellige mødesammenhænge eller fx skubbe de besværlige vejledningsopgaver videre til de kvindelige lektorer.

\section{BØRN, REPRODUKTION OG \\ TILBLIVELSER - \\ EN AKADEMISK BIOGRAFI}

Jeg kom til at interessere mig tidligt for betydninger af børn. Et par medstuderende og jeg var i Indien og skulle undersøge børnearbejde dér. Selv om jeg havde forfærdeligt hjemve dengang, så var det dybt interessant at få et mere nuanceret indblik i børnearbejde. Det er jo stadig et problematisk felt, når børn sidder og væver eller indgår i tændstik- eller fyrværkerifremstilling. Men allerede dengang var der også nogle andre sider og nuancer af børnearbejdet, som man ikke nødvendigvis kendte til. Jeg begyndte så at interessere mig for det indiske familiesystem og familieplanlægning i Indien. Man tvangssteriliserede jo dengang og forsøgte gennem forskellige tiltag i den indiske befolkningspolitik at regulere befolkningstallet. Og der kom jeg til at interessere mig for, hvilke betydninger børn har. I mit speciale (1989) startede jeg med at afklare nogle aspekter af den malthusianske tankegang i forbindelse med befolkningsproblematikken. Og det skrev jeg så om og begyndte også at undersøge, hvad børn egentlig betyder socialt og kulturelt. På det tidspunkt opdagede jeg, at der faktisk var et omfattende infertilitetsproblem i sub-Sahara Afrika. Der eksisterede, tror jeg, en generel forestilling om, at man i disse lande ikke havde problemer med at få børn. Men det var ikke rigtigt. Det var faktisk dybt tragisk for de kvinder, der ikke kunne få børn. Så det var den bevægelse fra at interessere sig for befolkningsproblemer i Indien og i sub-Sahara Afrika, der ligesom ledte mig hen til en interesse for barnløshed i Danmark. Samtidig havde jeg dog også en i an- 
tropologisk forstand eksistentiel krise. Mine oplevelser i Indien betød, at jeg kom i tvivl om, om jeg egentlig ville være antropolog, fordi jeg simpelt hen led så meget af hjemve, og jeg syntes, at feltarbejdet i Indien var en ret voldsom erfaring. Så da jeg kom hjem fra Indien var jeg i en veritabel krise. Jeg havde lbestået den antropologiske rites de passage ved at tage på feltarbejde langt væk, men tænkte samtidig: Jeg tror ikke, jeg skal være antropolog. Men på det tidspunkt så jeg Odinteatrets portrættering af Kirsten Hastrup, og der er en scene, hvor hun er på feltarbejde i Indien med sine børn, og de er syge osv., og så siger hun: "Island". Og så kom hun som bekendt til at forske i Island. Jeg tænkte dengang: Jamen, så kan man jo også gøre det. Man kan jo godt undersøge barnløshed i en dansk eller en europxisk kontekst. Den oplevelse blev afgørende for, at jeg blev sporet ind på at beskæftige mig med barnløshed, fertilitetsbehandling og slægtskab i Danmark. Jeg syntes, det var svært, fordi der på det tidspunkt var en meget stærk idé i antropologien om, at den rette og den rigtige etnografi, den foregik ikke i Danmark. Men jeg var også heldig, fordi jeg formulerede mit projekt på et tidspunkt, hvor der var en stigende interesse for reproduktionsteknologier, politisk, socialt og samfundsmæssigt. I mit feltarbejde i Danmark undersøgte jeg så, hvad det betyder, når man får børn på andre måder end den gængse, altså, hvad betyder det, når forplantningsteknologier som jeg kaldte dem dengang - bliver del af tilblivelsen; ikke kun børnenes tilblivelse, men også tilblivelsen som forældre. Jeg kan huske, at jeg skulle holde et oplæg om mit ph.d.-arbejde på et møde i Etnografisk Forening. Jeg var på herrens mark, jeg vidste faktisk ikke, hvad jeg skulle gøre. Ved et tilfælde kommer så en af mine kolleger ind og lægger Sarah Franklins artikel om Postmodern Procreation (1993) på mit bord og siger: "Måske skulle du prøve at læse denne her, den er sgu meget god." Jeg lægger den væk et øjeblik, men læser den, og bagefter ved jeg lige præcis, hvordan jeg skal organisere min afhandling og mit oplæg. I artiklen skriver Franklin blandt andet om procreation theories og understreger, at tilblivelsen eller tilblivelseshistorien ikke er universel, men netop er i pluralis. Der tænkte jeg, jamen det er selvfølgelig sådan, det skal være. Så Sarah Franklins arbejde hjalp mig til at se muligheden for at forankre min interesse i tilblivelser eller tilblivelseshistorier i et etnografisk univers og at sammenholde vores moderne teknologiske tilblivelser med andre måder at blive til på.

\section{AT FASTHOLDE NUANCER - (KØN OG) DET ETNOGRAFISKE ARBEJDE}

I mit arbejde om barnløshed og reproduktionsteknologier i Danmark blev det tydeligt, at det at bruge reproduktionsteknologier ikke kun handler om at få børn. Det handler, som jeg sagde før, om tilblivelser: tilblivelser af forældre, tilblivelser af fædre og mødre, og i den forbindelse også forskellige tilblivelser af køn eller i hvert fald forestillinger om forældreskabets kønnethed (Tjørnhøj-Thomsen 1999a, 1999b, 2002, 2003a, 2003b, 2004, 2005, 2007, 2009a, 2009b). I det her felt gør mennesker selvfølgelig køn, men de har også nogle meget stærke forestillinger om køn, og de generaliserer om køn, og hvad det kønnede er, og hvad det vil sige at være en rigtig mand eller kvinde. Ideen om, at man ved at indgå i tilblivelsen af børn på en bestemt måde får en særlig kønnet rigtighed, var meget fremtrædende i mit materiale. Denne forestilling er selvfølgelig blevet udfordret gevaldigt af både forskellige typer af partnerskaber og forskellige regnbuefamilier og af alle mulige konstellationer af familie og hvordan man ellers kan få børn. I den forening for ufrivilligt barnløse, hvor jeg udførte noget af mit feltarbejde, var der enkelte lesbiske. Men det var ugleset på det tidspunkt at være lesbisk og ønske sig børn. Der var stærke ideer om, hvad det ville sige at være rigtig barnløs og så bare være barn- 
løs. Men selv om der er flere forskellige muligheder for at få børn og også andre parkonstellationer end bare gifte heteroseksuelle, så er det ikke ensbetydende med, at man nødvendigvis anfægter eller udfordrer betydninger af det genetiske slægtskab, ideen om en bestemt familieform eller bestemte kønnede arbejdsfordelinger. Jeg har set mange eksempler på, at man også i regnbuefamilier lægger vægt på genetisk forbundethed, altså være genetisk beslægtet med sine børn. Så betydningen af at blive genetiske forældre er faktisk ret stærkt, selv om slægtskab, når man undersøger det nærmere, er noget, der bliver til over tid frem for at være der som en kendsgerning. Noget af det, der slog mig i min undersøgelse, var fx, hvordan især de barnløse kvinder følte sig udelukket fra de sammenhænge, hvor andre kvinder talte om deres børn eller børnerelaterede emner og i den forstand jo også reproducerede betydningen af biologisk og genetisk moderskab. Der er mange eksempler på generaliseringer af køn. Jeg ser dem også i mit arbejde om mænd, kræft og kræftrehabilitering. Her taler mændene om "vi mænd": Vi er sådan nogle, vi græder ikke, vi graver os bare ned i et hul i jorden, og så prøver vi at overstå det og sådan noget. Mændene generaliserer om det at være mand. Men som forsker skal man jo netop undersøge, hvad det så er, der ligger bag sådanne generaliseringer, og hvilke andre positioner der er mulige. For når man graver lidt i det, så finder man ud af, at det her billede af vi mand, og hvordan vi mond er, det er i høj grad også en kulturel idé, som jo i nogen grad påvirker, hvad de her mænd gør, men som på den anden side også hele tiden bliver anfægtet af det, de gør. Det synes jeg er rigtig interessant. Men der er ingen tvivl om, at de mænd, som er ramt af fx prostatakræft, er påvirket af, at kræftfeltet er blevet så kraftigt feminiseret. De føler, at der er fokus på brystkræft, og hver gang man ser et eller andet billede af en person med kræft, så er det en kvinde, der har brystkræft. Også pa- tientuddannelsestilbud består af bestemte typer af samværsformer, som nogle kvinder umiddelbart byder ind på, men altså ikke $\mathrm{i}$ så høj grad mændene. De mænd, vi snakkede med, interesserer sig ikke for at sidde og drøfte deres sygdom indgående. De vil gerne gøre noget andet. De vil gerne være aktive $\mathrm{i}$ en form for mandlige fællesskaber, hvor det ikke er sygdommen, der står i centrum for de drøftelser, de har. Men når jeg læser vores rapporter - eller måske snarere hører, hvordan indholdet af dem videreformidles i medierne - så kan jeg ikke undlade også at være bekymret for, at vi kan komme til at reproducere nogle bestemte forestillinger om køn og om, hvad det vil sige at være mand. Der er nemlig mange positioner, og jeg er ikke sikker på, at de samme ønsker gør sig grldende fx for yngre mænd. Men her ligger også helt klart en forskningsudfordring. Når man fx ikke har muligheder for at udføre bare lidt længere feltarbejder, så bliver det vanskeligere at bidrage med nuanceret viden, fx om at der er forskelle, i hvad der defineres som rigtig mand og maskulinitet, og at disse definitioner hele tiden er afhængige af de relationer og den situation, som mændene er i. Det er også svært at fastholde og insistere på vidensnuancer i en branche eller et samfund, som gerne vil have klare og helst entydige budskaber og anbefalinger. Nuancer opdager man i den etnografiske sammenhæng, og man skal ikke lade sig forføre af informanternes egne generaliseringer. I stedet må man interessere sig for, hvordan det kan være, at lige præcis den generalisering træder frem, og hvilke andre positioner ville være mulige i den.

FEMINISTIK ANTROPOLOGI, SLÆGTSKAB OG SITUERET VIDEN INSPIRERENDE TÆNKERE

Feministisk antropologi har givet antropologien et kæmpe boost og i særlig grad den generation af feminister, der kom efter David Schneider (1980) og hans interesse $\mathrm{i}$ 
slægtskab: fx Sylvia Yanagisako and Carol Delaney (1995), Marilyn Strathern (1992a, 1992b), Sarah Franklin (1997), Kath Weston (1991). Kath Westons bog Families We Choose (1991) har gjort et særligt indtryk på mig. Det var en fantastisk god bog, og hendes arbejde synes jeg virkelig var vigtig for mig som også Franklins. Så hvis jeg skulle sige, at jeg skrev mig ind i en eller anden form for tradition, det har jeg det ikke særlig godt med, men så nødvendigvis er det helt klart i efterdønningerne af Schneider og Carol Delaney og Sylvia Yanagisako. Det er helt klart, at mit afhandlingsarbejde skriver sig ind i dette felt, hvor feministiske antropologer gør op med nogle bestemte ideer om biologi og køn ved at udforske samspillet mellem køn, slægtskab, reproduktion og teknologi. En anden inspirationskilde var Donna Haraway (1988). Hendes idé om en anden form for objektivitet i Situated Knowledges installerede bevidstheden om, at vi ikke skal løbe skrigende bort, når folk siger objektivitet. Vi kan godt inden for kvalitativ og etnografisk forskning tage fat om de begreber og prøve at behandle dem på en anden måde. Den synes jeg virkelig var god, og jeg kan stadigvæk læse den og tænke: Lige præcis - man kan ikke vide alt, der findes ikke et sted, hvorfra du kan stå og kigge ud over det hele, al viden skal ses fra et bestemt synspunkt og er situeret. Bare at introducere til og fastholde denne tanke er virkelig vigtig også i dag.

\section{LITTERATUR}

- Franklin, Sarah (1993): Postmodern procreation: Representing reproductive practice, in: Science as Culture/3 (4).

- Franklin, Sarah (1997): Embodied progress: a cultural account of assisted conception. Routledge, New York.

- Haraway, Donna (1988): Situated Knowledges: The Science Question in Feminism and the Privilege of Partial Perspective, in: Feminist Studies/14 (3).
- Reiter, Rayna R. (ed.) (1975): Toward an Antbropology of Women. Monthly Review Press, New York.

- Schneider, David (1980): American kinship: a cultural account. University of Chicago Press, Chicago.

- Strathern, Marilyn (1992a): Reproducing the Future. Essays on anthropology, kinship and the new reproductive technologies. Manchester University Press, Manchester.

- Strathern, Marilyn (1992b): After nature: English kinship in the late twentieth century. Cambridge University Press, Cambridge.

- Tjørnhøj-Thomsen, Tine (1999a): Tilblivelseshistorier. Barnløshed, slagtskab og forplantningsteknologi i Danmark. Ph.d., Insitut for Antropologi, Københavns Universitet.

. Tjørnhøj-Thomsen, Tine (1999b): "Det føles ikke-mandigt på en måde": mænd og infertilitet, i: Kvinder, Køn \& Forskning 1999/3.

- Tjørnhøj-Thomsen, Tine (2002): Fra barnløshed til forældreskab, i: Kvinder, Køn \& Forskning 2002/1.

- Tjørnhøj-Thomsen, Tine (2003a): Børns sociale og kulturelle betydninger: et barnløst perspektiv på børn, i: Barn/l.

- Tjørnhøj-Thomsen, Tine (2003b): Childlessness, procreative technologies and the creation of new mythologies, in: Folk: Journal of the Danish Ethnographic Society/45.

- Tjørnhøj-Thomsen, Tine (2004): Slægtskab. Tilblivelse, forbundethed og frllesskab, i: Kirsten Hastrup (red.): Viden om verden. En grundbog $i$ antropologiske analyse. Hans Reitzels Forlag, København.

- Tjørnhøj-Thomsen, Tine (2005): Close encouunters with infertility and procreative technology, in: Richard Jenkins, Hanne Jessen \& Vibeke Steffen (eds.): Managing uncertainty: ethnographic studies of illness, risk and the struggle for control. Museum Tusculanum Press, Copenhagen. - Tjørnhøj-Thomsen, Tine (2007): Barnløses billeder af rigtige familier, i: Lene Andersen \& Palle Ove Christiansen (red.): En rigtig familie: mellem nye og gamle idealer. C.A. Reitzels Forlag: København.

· Tjørnhøj-Thomsen, Tine (2009a): Hjem uden børn, i: Tidskriftet Antropologi/59-60.

. Tjørnhøj-Thomsen, Tine (2009b): "It's a bit unmanly in a way": Men and Infertility in Denmark, in: Marcia C Inhorn, Tine Tjørnhøj-Thomsen, Helene Goldberg \& Maruska la Cour Mosegaard (eds.): Reconceiving the Second Sex. Men, Masculinity, and Reproduction. Berghahn Books, New York. 
Weston, Kath (1991): Families we choose: lesbians, gays, kinship. Columbia University Press, New York.
· Yanagisako, Sylvia \& Delaney, Carol (eds.) (1995): Naturalizing Power: Essays in Feminist Cultural Analysis. Routledge, New York. 